\title{
СУДОВИЙ ЗАХИСТ ЯК ЮРИДИЧНА ГАРАНТІЯ ПРАВ ОСІБ, ЗВІЛЬНЕНИХ ЗА СИСТЕМАТИЧНЕ ПОРУШЕННЯ ТРУДОВИХ ОБОВ'ЯЗКІВ
}

Постановка проблеми. Правові проблеми судового захисту порушених прав працівників становлять інтерес для науки трудового права. Наукове дослідження судового порядку вирішення індивідуальних трудових розбіжностей під час звільнення працівника за систематичне порушення трудових обов'язків у сучасних умовах розвитку України становить інтерес як з позиції практики функціонування судової системи, так і обгрунтування теоретичних основ судового розв'язання названих спорів і конфліктів в умовах ринкової економіки.

Стан дослідження. Свого часу питання судового захисту трудових прав працівників активно досліджувалось науковцями І.В. Лагутіною, В.В. Лазором, I.О. Іонніковою, Н.Б. Болотіною, І.В. Кисельовим, В.І. Смолярчуком та ін., на які я посилаюсь у проведенні власного дослідження. Слід наголосити на тому, що досить вагомим $є$ внесок цих та інших учених у розвиток доктрини трудового права, зокрема теорії судового захисту трудових прав, процедури врегулювання трудових спорів (конфліктів). Беручи до уваги стан та динаміку розвитку суспільства та держави, необхідність утвердження та якісного реформування судової гілки влади, процедури здійснення правосуддя, ключового значення набуває проблема вдосконалення права на судовий захист трудових прав як важливий складник організації системних соціально-економічних, судово-правових реформ. Таким чином, метою цієї статті є визначення шляхів удосконалення правового регулювання судового захисту як юридичної гарантії прав працівників, звільнених за п. 3 ст. 40 КЗпП України в умовах сьогодення.

Виклад основних положень. Принципи здійснення судового захисту передбачені Міжнародним пактом про громадянські та політичні права 1966 р. [1], водночас у Загальній декларації прав людини 1948 р. проголошено, що кожна людина має право на ефективне поновлення у правах компетентними національними судами у разі порушення її основних прав, наданих конституцією або законом [2]. Принцип ефективного поновлення порушених прав поступово реалізується у національному судочинстві. Конституція України (ч. 1 ст. 55) розширюе можливості судового захисту порушених трудових прав. Це конституційне право відображено і у нормах галузевого законодавства: право на звернення до суду для вирішення трудових спорів передбачено у ч. 2 ст. 2 КЗпП; право працівників на захист своїх трудових прав у суді міститься в п. 19 ст. 2 Проекту Трудового кодексу України; відповідно до ч. 1 ст. 4 Цивільного процесуального кодексу України кожна особа має право звернутися до суду за захистом своїх порушених, невизнаних або оспорюваних прав.

$\mathrm{У}$ юридичній літературі зазначається, що право на судовий захист - спосіб захисту прав, свобод і законних інтересів учасників суспільних правовідносин фізичних та юридичних осіб. При цьому суд, здійснюючи правосуддя на засадах верховенства права, забезпечує захист гарантованих Конституцією України та 
законами прав і свобод людини і громадянина, прав і законних інтересів юридичних осіб, інтересів суспільства і держави [3, с. 29]. І.В. Дашутін наголошує, що право на судовий захист - це передбачена законодавством можливість фізичних та юридичних осіб захищати свої права в судах загальної і конституційної юрисдикції. Це право слід розглядати двояко: з одного боку, як одне з конституційних прав людини в державі нарівні з іншими політичними, економічними, соціальними й культурними правами, а з іншого - як право, що закріплює спеціальний механізм захисту всіх без винятку вищезазначених прав [4, с. 12]. Тому право на судовий захист реалізується через організацію судочинства та здійснення правосуддя. Нерідко значення юридичних гарантій насамперед пов'язується із забезпеченням прав людини від будь-яких порушень. Безперешкодна реалізація права на працю значною мірою залежить від тих юридичних гарантій, що діють на етапі припинення трудових правовідносин і забезпечують законність звільнень працівників. Як відзначає С.В. Селезень, гарантії - це закріплені у законодавстві умови й засоби, що забезпечують суб'єктам трудових і похідних від них правовідносин реальні можливості для охорони, безперешкодного здійснення, відновлення (у разі порушення) їх суб’єктивних прав і належного виконання ними обов'язків [9, с. 12].

Розглядаючи тему дослідження, слід відзначити, що специфічним для трудового права є діяльність такого органу з відновлення трудових прав працівників, як комісія з трудових спорів. Відповідно до ст. 224 КЗпП України комісія з трудових спорів є обов'язковим первинним органом з розгляду трудових спорів, що виникають на підприємствах, в установах, організаціях, за винятком спорів, зазначених у статтях 222, 232 цього Кодексу. Трудовий спір підлягає розглядові в комісії з трудових спорів, якщо працівник самостійно або за участю профспілкової організації, що представляє його інтереси, не врегулював розбіжності у безпосередніх переговорах з роботодавцем.

О.М. Ярошенко та А.М. Слюсар відзначають, що у разі виникнення індивідуального трудового спору багато хто з правників прагне одразу подати позов до суду, навіть не намагаючись як слід розібратися в проблемі, тоді як більшість спорів можна вирішити цілком мирним шляхом і в межах підприємства, установи, організації чи структурного підрозділу. Для цього на підприємствах і створюються комісії з трудових спорів. Вони покликані примирити сторони, що сперечаються, до звернення до суду, а можливо, і запобігти такому зверненню, адже для сторін спору воно неминуче пов'язано з матеріальними витратами та різними незручностями [5, с. 445]. Аналізуючи норми ст. 223 КЗпП України, можна з упевненістю говорити про те, що комісії з трудових спорів здебільшого залежні від роботодавця: по-перше, половина членів такої комісії є представниками роботодавця, які апріорі підтримують його позицію, інша половина - робітники, які також, з огляду на засади трудових відносин, підпорядковуються роботодавцю і матеріально залежні від нього; по-друге, організація діяльності комісії, зокрема організація діловодства, облік та зберігання заяв працівників і справ, підготовка та видача копій рішень тощо, здійснюється роботодавцем. У таких умовах працівникам не варто чекати належного захисту трудових прав від указаної комісії. Тому слід погодитися з О.М. Ярошенком та A.М. Слюсарем у тому, що комісії з трудових спорів нині можна розглядати лише 
як примирний орган, який покликаний примирити сторони, що сперечаються, до звернення до суду. Без сумніву, велике значення для гарантування трудових прав працівників, зокрема під час укладення, зміни та розірвання трудового договору, має діяльність судів з поновлення порушених прав.

Особливістю права на судовий захист як юридичної гарантії є те, що у справах про звільнення працівник може звернутися до суду лише у місячний строк із дня вручення копії наказу про звільнення або з дня видачі трудової книжки (ч. 1 ст. 233 КЗПП). У цій статті початок обчислення місячного строку визначено альтернативно i, на думку вчених із трудового права, його слід обчислювати 3 дня, коли вчинена більш рання дія. Свою точку зору автори обгрунтовують, посилаючись на те, що обчислення строку з дня вручення копії наказу про звільнення чи трудової книжки є лише конкретизацією загального правила про обчислення строку з дня, коли працівник дізнався про порушення його суб'єктивних трудових прав [6, с. 780; 7, с. 98]. На думку I.А. Іоннікової, така позиція є помилковою. Насамперед під час розірвання трудового договору з ініціативи роботодавця законодавець статтею 47 КЗпП України зобов'язав його в день звільнення видати працівникові копію наказу про звільнення та видати належним чином оформлену трудову книжку. Видання лише наказу про звільнення і вручення його працівнику, пише автор, не є підставою вважати, що звільнення працівника проведено належним чином та відповідно до вимог трудового законодавства, оскільки невручення роботодавцем трудової книжки працівнику позбавляє останнього конституційного права на працю. Саме з моменту вручення трудової книжки, у якій буде відповідний запис про звільнення із зазначенням підстави та з посиланням на закон, слід обчислювати місячний строк для звернення до суду із позовом про поновлення на роботі [8, с. 13]. Можна вважати, що така залежність збігу строку звернення до суду від видачі трудової книжки є неправильною, оскільки із копії наказу працівник може дізнатися про факт порушення його права на працю. Тому працівнику досить отримати один із зазначених документів та вважати початком обчислення строку звернення до суду день, коли було видано перший документ.

Важливою юридичною гарантією трудових прав працівників є норма-дозвіл, яка звільняє останніх від сплати судового збору у разі звернення до суду із позовом про вимоги, що випливають із трудових правовідносин. Ця норма забезпечує всім працівникам доступність звернення до суду та гарантує реальну можливість реалізації свого права на судовий захист порушених трудових прав. Тому, на нашу думку, заслуговує на увагу позиція авторів проекту ТКУ передбачити відповідну юридичну гарантію у новому кодексі (ст. 365 «Звільнення працівника від судових витрат»), що забезпечить можливість звернення до суду працівників із різним матеріальним становищем, а, відповідно, сприятиме підвищенню ефективності дії цієї норми-гарантії.

Ефективність права на судовий захист як юридичної гарантії під час розірвання трудового договору полягає у виконанні рішення суду. Гарантія-обов'язок, закріплена у ч. 5 ст. 235 КЗпII, зобов'язує роботодавця негайно виконати судове рішення про поновлення на роботі незаконно звільненого або незаконно переведеного на іншу роботу працівника. Роботодавець зобов' язаний допустити такого працівника 
до виконання трудових обов’язків на колишній посаді (роботі) із наступного дня після винесення судом відповідного рішення. Такий порядок встановлено з метою якнайшвидшого та ефективного поновлення порушеного права (ст. 65 Закону України «Про виконавче провадження» від 21 квітня 1999 року). Винятків з цієї гарантії немає, тому відсутність у роботодавця роботи (посади), яку виконував незаконно звільнений або переведений працівник, не звільняє представника роботодавця від обов'язку виконати судове рішення про поновлення на роботі.

За відмови роботодавця видати наказ про поновлення працівника на роботі та допуск його до роботи рішення суду підлягає виконанню у примусовому порядку, що забезпечують встановлені законодавством юридичні гарантії - норми-санкції. По-перше, за затримку роботодавцем виконання рішення суду про поновлення на роботі незаконно звільненого працівника передбачено гарантію-санкцію, яка зобов' язує роботодавця виплатити працівнику середній заробіток за весь час затримки (ст. 236 КЗпП), тобто з дня винесення судового рішення до дня його виконання. Крім того, за затримку виконання роботодавцем рішення суду про поновлення працівника на роботі без поважних причин передбачено гарантії-санкції, які дають змогу державному виконавцю застосувати до посадової особи, зобов’язаної вчинити дії щодо виконання рішення суду, штрафні санкції у розмірі від ста до трьохсот неоподатковуваних мінімумів доходів громадян (ч. 1 ст. 75 Закону України «Про виконавче провадження»). За повторне невиконання рішення суду передбачено застосування гарантії-санкції, що полягає у накладанні на роботодавця штрафу у подвійному розмірі. У разі подальшого невиконання судового рішення державний виконавець порушує клопотання перед судом про кримінальну відповідальність відповідних осіб (ч. 3 ст. 75 Закону України «Про виконавче провадження»). Наведені гарантії-санкції забезпечують примусове виконання судових рішень, тому, відповідно, і права на судовий захист як юридичної гарантії з метою поновлення порушеного права.

Дієвість права на судовий захист як юридичної гарантії під час звільнення працівника за п. 3 ст. 40 КЗпП проявляється у покладенні на роботодавця, який незаконно звільнив працівника (що встановлено у судовому порядку), санкції у вигляді обов’язку виплатити цьому працівникові середній заробіток за час вимушеного прогулу або різницю в заробітку за час виконання нижчеоплачуваної роботи, але не більше як за один рік (ч. 2 ст. 235 КЗпП). Виплата заробітку за весь час вимушеного прогулу можлива, якщо заява про поновлення на роботі розглядається більше одного року не з вини працівника. Слід зазначити, що російський законодавець відмовився від обмеження строку виплати середнього заробітку одним роком, встановивши обов'язок роботодавця виплачувати середній заробіток або його різницю за весь час вимушеного прогулу чи виконання нижчеоплачуваної роботи (ч. 2 ст. 394 ТК РФ). Аналогічної точки зору дотримується Н.М. Хуторян та наголошує про необхідність внести відповідні зміни у вітчизняне трудове законодавство [10, с. 224]. Слід зазначити, що заслуговує на увагу намір авторів проекту ТКУ закріпити подібне положення в п. 1 ч. 2 ст. 366.

Право на судовий захист як гарантія-дозвіл покликане нині виконати важливе завдання: забезпечити та утвердити цінність особи працівника у сфері праці. Адже 
саме суди користуються найбільшою довірою працівників як захисників своїх трудових прав. Тому завданням вітчизняного законодавця на сучасному етапі $є$ формулювання змісту правових норм таким чином, щоб вони могли забезпечити ефективний та адекватний ринковим відносинам захист трудових прав працівників.

Саме тому є більш значущою проблема судової реформи, набуває актуальності проблема створення поряд з конституційними, адміністративними судами та судами загальної юрисдикції спеціалізованих судів або спеціалізованих складів, секторів у судах.

Спеціалізовані трудові суди є в Австрії, Бельгії, Великобританії, Німеччині, Данії, Іспанії, Швеції, Швейцарії, Сполучених Штатах Америки, Франції, Японії, Канаді та інших країнах. Спеціалізована трудова юстиція, що функціонує за кордоном багато років (наприклад, у Франції - близько 200 років), повністю себе виправдала, довела на практиці свою необхідність як одного із корисних інститутів соціально-правової інфраструктури, досить ефективну у вирішенні трудових конфліктів з максимальним урахуванням інтересів сторін, що спорять, і всього суспільства і тим самим у забезпеченні соціального миру. Досвід діяльності трудових судів зарубіжних країн є корисним для України, вимагає вивчення, оскільки судовий порядок вирішення спорів має активно розвиватися за умови ринкових відносин, що забезпечить належний захист прав працівників і реалізацію конституційного права громадян на судовий захист. На мою думку, чинна у цей час система судового захисту у галузі трудових правовідносин відстає від вимог, що висуваються до якості розгляду спорів, під час вирішення яких мають враховуватися і знаходити своє втілення принципи трудового права (свобода праці та заборона примусової праці, рівність прав і можливостей та заборона дискримінації у сфері праці; право на справедливу заробітну плату, що забезпечує рівень життя, гідний для самого працівника і членів його сім’ї, право на справедливі та безпечні умови праці тощо). Без цього неможливе здійснення реального захисту прав і законних інтересів працівників. На відміну від цивільного права, яке виходить із рівності суб'єктів цивільних відносин, трудове право визнає фактичну нерівність суб'єктів трудових правовідносин, а саме залежність працівника від роботодавця. Принципи цивільного процесуального права не сприяють прийняттю законних та обгрунтованих рішень у сфері праці. У зв’язку з цим виникає необхідність у створенні такої процесуальної форми розгляду і вирішення трудових спорів, яка дала би змогу найбільш ефективно застосувати норми трудового права, а саме Трудового процесуального кодексу. ТКП має регулювати всі процесуальні відносини, що виникають під час вирішення індивідуальних і колективних трудових спорів.

Трудовий процесуальний кодекс має передбачити низку процесуальних гарантій захисту прав, свобод і законних інтересів працівників, роботодавців та інших суб'єктів трудових правовідносин, а також гарантувати юридичну рівність сторін у врегулюванні розбіжностей між ними. Фактично йдеться про формування нової галузі процесуального права. Однак для цього є необхідними не тільки наявність процесуальних особливостей розгляду трудових спорів у судах, але й існування масиву правових норм, достатнього для формування повноцінної галузі права. Оскільки жодна галузь матеріального права не може обійтися без процедурних 
норм, то внесення таких норм (про порядок прийняття на роботу, порядок укладення трудового договору, порядок притягнення до дисциплінарної чи матеріальної відповідальності тощо) до ТПК може послужити поштовхом до руйнування галузі трудового права всередині. На нашу думку, концепція Трудового процесуального кодексу потребує більш глибокої розробки, а вирішення питання про виникнення нової процесуальної галузі права (трудового процесуального права) є натепер передчасним. Тому вважаємо за доцільне доповнити ЦПК відповідними статтями, наприклад, передбачити санкцію у вигляді штрафу за неподання сторонами доказів на вимогу суду.

На підставі викладеного можна дійти висновку, що важливою гарантією права на працю є те, що трудовий договір з працівником за ініціативи роботодавця може бути розірвано лише за наявності підстав, передбачених законодавством України і з додержанням встановлених законом гарантій права на працю. Варто звернути увагу на ту обставину, що звільнення працівника за ініціативи роботодавця не є його обов' язком, а тільки правом. Юридичні гарантії є тими правовими засобами, на які покладено завдання забезпечити кожному безперешкодну реалізацію всього комплексу наданих йому трудових прав.

\section{Jimepamypa}

1. Міжнародний пакт про громадянські та політичні права: Міжнародний пакт ООН від 16.12.1966. URL: http://zakon2.rada.gov.ua/laws/ show/995_043.

2. Загальна декларація прав людини: Декларація ООН від 10.12.1948. Голос України від 10.12.2008. № 236 .

3. Юридична енциклопедія: в 6 т. / редкол.: Ю.С. Шемшученко (голова редкол.) та ін. Кииї : «Укр. енцикл.», 1998. Т.5. П-С. 2003. 736 с.

4. Дашутін І.В. Правове регулювання судового захисту трудових прав громадян : автореф. дис... канд. юрид. наук : 12.00 .05 . Харків, 2008. 20 с.

5. Трудове право : підручник / В.В. Жернаков, С.М. Прилипко, О.М. Ярошенко та ін.; за ред. В.В. Жернакова. Харків : Право, 2012. С. 445.

6. Стичинський Б.С. Науково-практичний коментар до законодавства України про працю / Б.С. Стичинський, І.В. Зуб, В.Г. Ротань. 8-е вид., доп. і перероб. Київ : Видавництво А.С.К., 2007. 944 с.

7. Ситницька О.А. Юридичні гарантії права на працю та права на відпочинок за трудовим законодавством України : монографія. Хмельницький : Видавництво Хмельницького університету управління та права, 2010. 168 с.

8. Іоннікова І.А. Правове регулювання розірвання трудового договору з ініціативи роботодавця : автореф. дис. на здобуття наук. ступеня канд. юрид. наук : спец. 12.00.05 «Трудове право, право соціального забезпечення». Харків, 2004. 20 с.

9. Селезень С.В. Особливості припинення трудового договору за п. 2 ст. 41 Кодексу законів про працю України : автореф. на здобуття наук. ступеня канд. юрид. наук : спец. 12.00.05 «Трудове право, право соціального забезпечення». Львів, 2009. 19 с.

10. Хуторян Н.М. Теоретичні проблеми матеріальної відповідальності сторін трудових правовідносин : монографія. Київ : Інститут держави і права ім. В.М. Корецького НАН України, 2002. 264 с.

\section{Анотація}

Прогонюк Л. Ю. Судовий захист як юридична гарантія прав осіб, звільнених за систематичне порушення трудових обов'язків. - Стаття.

Стаття присвячена визначенню шляхів удосконалення правового регулювання судового захисту як юридичної гарантії прав працівників, звільнених за п. 3 ст. 40 КЗпП України, в умовах сьогодення.

Ключові слова: трудові спори, судовий захист, трудові обов'язки, проект Трудового кодексу, юридичні гарантіі. 


\section{Аннотация}

Прогонюк Л. Ю. Судебная защита как юридическая гарантия прав лиц, уволенных за систематическое нарушение трудовых обязанностей. - Статья.

Статья посвящена определению путей усовершенствования правового регулирования судебной защиты как юридической гарантии прав работников, уволенных по п. 3 ст. 40 КЗоТ Украины, в современных условиях.

Ключевые слова: трудовые споры, судебная защита, трудовые обязанности, проект Трудового кодекса, юридические гарантии.

\section{Summary}

Prohoniuk L. Yu. Judicial remedy as a legal guarantee of the rights of individuals dismissed for systematic violation of labor duties. - Article.

The article is devoted to determination of the ways to improve the legal regulation of judicial remedy as a legal guarantee of the rights of employees dismissed pursuant to part 3 of Art. 40 of the Labor Code of Ukraine in current conditions.

Key words: labor disputes, judicial remedy, labor obligations, draft of the Labor Code, legal guarantees. 